\author{
KAROLINA POSPISZIL \\ (D) https://orcid.org/0000-0001-7622-5394 \\ Uniwersytet Śląski \\ Katowice \\ JOLANTA TAMBOR \\ (D) https://orcid.org/0000-0002-0801-3821 \\ Uniwersytet Śląski \\ Katowice
}

\title{
Polska różnorodna w różnorodnym świecie. Prescriptum
}

Temat prezentowanego numeru - „Polska różnorodna” - może wydawać się na pierwszy rzut oka oksymoronem. Ale pomieszczone w numerze teksty pokazują, że ani polskie społeczeństwo, ani polska kultura nie są tak homogeniczne, jak się powszechnie uważa. Na polską różnorodność składają się mniejszości etniczne i narodowe, a także wspólnoty regionalne czy regionalno-kulturowe, grupy etniczne i etnograficzne - mówiące i tworzące w swoich etnolektach, językach, dialektach i gwarach.

W numerze przedstawiamy zaledwie wycinek tego bogactwa, skupiając się przede wszystkim na współczesności; jednak lekty i kultury, o których piszą autorzy artykułów, od dawna współtworzyły Polskę i polskość, przyczyniały się do kulturowego rozwoju społeczeństwa, narodu, państwa polskiego. To wiedza o zakotwiczeniu w kulturach i językach mniejszych (które rozumiemy tutaj zarówno jako kultury/języki mniejszości narodowych i etnicznych, jak i kultury/języki/lekty regionalne, pograniczne, języki i kultury kresów i obrzeży) lub inspiracji nimi dzieł literatury polskiej, także tych największych, pozwala je lepiej zrozumieć, pełniej odczytać, próbować dotrzeć do wszystkich sensów - przywołajmy chociażby Pana Tadeusza Adama Mickiewicza, Trylogie Henryka Sienkiewicza, Pržedwiośnie czy kaszubskie fragmenty Wiatru od morza 
Stefana Żeromskiego, Doline Issy Czesława Miłosza, ale i twórczość Elizy Orzeszkowej, Aleksandra Fredry, niemal zapomnianego Walentego Roździeńskiego czy góralskie opowiadania Na skalnym Podhalu Kazimierza Przerwy-Tetmajera. Wnikliwa lektura wielu istotnych dla narodowej świadomości Polaków utworów pozwoli odkryć ich wielokulturowość oraz specyficzną odmienność językowa, multilektalność (inkrustację - w większym lub mniejszym stopniu - tekstów elementami gwar, dialektów, języków regionalnych czy pogranicznymi naleciałościami innojęzycznymi).

Te wszystkie zjawiska językowe i kulturowe współtworzą obraz polskości i Polski. Łącznie ze wspólnotami niedefiniującymi się jako polskie, a funkcjonującymi w granicach państwa polskiego dziś lub w przeszłości i będacymi częścią jego kultury. I łącznie z tymi, które doświadczają pewnej „podwójności”, a nawet „potrójności”, czyli wspólnotami szeroko rozumianego pogranicza, kresów - będących zawsze pograniczem. Dziś kresy mają nieco odmienne znaczenie, przesunięciu uległa dominanta pojęcia. To już nie tylko tradycyjne polskie, pisane często dużymi literami Kresy Wschodnie, które zyskały literackie uznanie i społeczny prestiż, bo wiązane są z największymi nazwiskami w polskiej literaturze, ale także zachodnie (tu warto wspomnieć o artykule Rolanda Martiego, pokazującego skomplikowane relacje polsko-niemiecko-łużyckie) czy południowe z polsko-niemiecko-czeskim kontaktem językowym Śląska i choćby polsko-słowacko-ukraińsko-rusińskim w okolicach zamieszkanych przez Lemków. Kresy, pogranicza, obrzeża sa niezwykle ciekawe, bo wciąż stawiaja nowe wyzwania przed obserwatorami i badaczami. Wciąż nowe, bo kontakt kultur i języków wytwarza nieustannie kolejne fakty, fenomeny, zjawiska, dotąd niezbadane, bo wcześniej nieistniejące (tu warto wskazać teksty Anastazji Reis o „nowej” łemkowszczyźnie).

W ciagu ostatnich trzydziestu lat znacznie wzrosło zainteresowanie językami i kulturami mniejszymi. Z jednej strony możemy mówić o braku cenzury i swobodzie badań naukowych, z drugiej jednak zauważalny jest ogólnoświatowy zwrot ku temu, co mniejsze i lokalne, choć szczytowe nasilenie tego zwrotu przypadało na przełom XX i XXI wieku, co w Europie można wiązać choćby z Europejska karta jezykeów regionalnych lub mniejszościonych i aktywnościa mniejszości w wielu krajach w związku m.in. z ratyfikacją Karty i uchwalaniem państwowych ustaw inspirowanych Karta. Na całym świecie powstaja projekty rewitalizacji zagrożonych wyginięciem kultur i języków, w Polsce najprężniej w tym zakresie działaja wspólnoty regionalne (Kaszubi, Ślązacy) oraz mniejszości etniczne i narodowe (Lemkowie, Wilamowianie, którzy - to atrakcyjna ciekawostka - swe działania rewitalizacyjne związali z potomkami Azteków). 
Częścią aktywności rewitalizacyjnych czy, z innego punktu widzenia, odbudowy, powstawania / konsolidowania wspólnot kulturowych (regionalnych, etnicznych) wokół kulturowo-językowego centrum jest także twórczość literacka. Coraz liczniejsze są publikacje zarówno w skodyfikowanych i uznanych przez polskie prawo językach (np. łemkowskim, kaszubskim), jak i w lektach jeszcze czekających na status języka regionalnego (wilamowski, śląski) bądź odtwarzanych (pruski, mazurski). Wspomniane działania świadczą o potrzebie identyfikacji ze wspólnotą, często identyfikacji zwielokrotnionej, wielopiętrowej (np. Kaszuba-Polak-Europejczyk), świadczą także o potrzebie pielęgnowania bogactwa rodzimej kultury. Spojrzenie z tej perspektywy pozwala odkryć, że wielu $z$ nas jest $\mathrm{w}$ gruncie rzeczy zakorzenionych w różnych kulturach i (czasem) językach, czy np. w językach i dialektach, regiolektach. Wielu z nas jest więc ludźmi pogranicza - a samo pogranicze, jak pisała badaczka interkulturowości, Maria Bobrownicka - jest wszędzie. Granice bowiem są nieodłącznym elementem otaczającej nas rzeczywistości: granice pokoleniowe, kulturowe, etniczne, narodowe... Są też ciekawym faktem i obiektem badawczym. Koniec XX i początek XXI wieku przyniósł z jednej strony potrzebę i próby zacierania różnorakich granic - internet, powszechność kolejnych ogólnoświatowych komunikatorów, łatwość podróżowania do najbardziej odległych miejsc globu wytworzyły zjawisko totalnej wręcz w niektórych wymiarach globalizacji, o wiele głębszej niż prorokowało to pojęcie i ujęcie ,globalnej wioski" Herberta Marshalla McLuhana. Jednak z drugiej strony przełom stuleci wytworzył zjawisko odwrotne. II połowa XX wieku przyniosła w wielu krajach tendencje do ujednolicania, monokulturowości i monoetniczności. Jak się okazało, często były to rozwiązania siłowe i dążności odśrodkowe wybuchły z ogromną moca na początku lat 90. poprzedniego stulecia, gdy runął komunizm i demokratyzowała się cała Europa, dopuszczając do bogatego „zachodu” coraz więcej obrzeży, krajów o odmiennej drodze powojennego funkcjonowania. Już w 1992 roku opracowano Europejska karte jezykón regionalnych lub mniejszościonych, weszła ona w życie w 1998 r. po ratyfikowaniu jej przez pierwsze 5 państw - należy uznać za fakt znamienny, że w tej pierwszej piątce była Chorwacja, jeden z krajów, który jest symbolem owych nowych odśrodkowych dążeń tożsamościowych. Zatem z jednej strony globalizacja, a z drugiej wytwarzanie i reaktywacja nowych granic między narodami, kulturami, a więc i reprezentującymi je językami. Nie sposób dzisiaj choć przez moment nie być równocześnie uczestnikiem dwóch światów, dwóch kultur, nie sposób nie zdawać sobie sprawy, że nie funkcjonujemy w izolacji, że każdy kontakt $\mathrm{z}$ innym zmienia nas i rozwija. 
Prezentowany numer jest bardzo różnorodny, pomieszczone w nim zostały teksty języko-, literaturo- i kulturoznawcze dotyczące obecnych w Polsce kultur mniejszych i ich języków oraz kultur i języków na styku z polszczyzną i z Polską, skupione przede wszystkim na zagadnieniach szczegółowych, w dużej mierze ze względu na ograniczenia formalne artykułów. Pierwsza część prezentowanych rozpraw poświęcona jest językom i kulturom regionalnym, a otwieraja ja teksty wyznaczające dwie perspektywy spojrzenia na interesująca nas problematykę. To studium Tomasza Wicherkiewicza, poznańskiego badacza języków mniejszościowych i regionalnych, w którym autor prezentuje perspektywę glottopolityczną i ekolingwistyczna.. Drugi to artykuł Małgorzaty Mikołajczak poświęcony skomplikowanym związkom kultury/literatury i idei (ideologii) narodu oraz wyznaczający ścieżki, którymi podąża znaczna część autorów rozpraw literaturo- i kulturoznawczych. Regionom, także tym o skomplikowanym statusie mikroregionalnym, zostały poświęcone teksty Artura Jabłońskiego (Kaszuby), Ewy Michny, Wojciecha Hofmańskiego (Górny Śląsk), Justyny Szlachty-Ignatowicz i Tomasza Wicherkiewicza (Wilamowice) oraz Kamili Gieby (Ziemie Zachodnie). O językach i kulturach mniejszości etnicznych i narodowych piszą Anastasia Reis (Lemkowie), Maciej Witkowski, Monika Pakura (Romowie), Mustafa Switat (Arabowie) oraz Anna Sobecka (Żydzi). Wypowiedzi dotyczące terytorium Polski zostały wzbogacone szerszymi kontekstami na temat pogranicznych kontaktów niemiecko-polsko-łużyckich (Roland Marti), literatury mniejszości łemkowskiej (rusińskiej) na Słowacji (Ivana Slivková), a także problematyki dyglosji (Aldona Skudrzyk) i roli języka w kształtowaniu tożsamości młodego pokolenia (Emilia Bańczyk). Pierwszy tegoroczny numer już tradycyjnie zamykaja przeglądy w postaci stałych i lubianych rubryk: „Półki literackiej” Agnieszki Nęckiej oraz „Półki filmowej” Agnieszki Tambor, kończą go rozważania Elżbiety Dutki o książce Katarzyny Taborskiej o „literaturze miasta” i „pisaniu miasta” (Gorzowa Wielkopolskiego) i Wioletty Hajduk-Gawron o kondycji współczesnej glottodydaktyki na marginesie książki Przemysława Gębala.

Mniejszości etniczne i językowe, kulturowo-językowe grupy regionalne wciąż fascynują. Czasem otwarciem i poszukiwaniem kontaktu z wszelkimi innymi, czasem odizolowaniem w ścisłych granicach, kuszących do ich przekraczania zarówno tych, którzy są w nich zamknięci, jak i zewnętrznych obserwatorów. Bo inność od zarania dziejów była i jest dla ludzi pociagająca, skłania do porównań, wabi egzotyką i odmiennościa, jest motorem poznania i nieustannego rozwoju. 